\title{
The hydrological regime of the Prahova River along Carpathian and Subcarpathian stretch
}

\author{
Livioara Brașovanu ${ }^{1}$, Daniela Elena Gogoașe Nistoran², Iuliana Armaș ${ }^{1}$ \\ ${ }^{1}$ University of Bucharest, Faculty of Geography \\ ${ }^{2}$ University „Politetechnica” of Bucharest, Department of Hydraulics, \\ Hydraulic Machines and Environmental Engineering
}

\begin{abstract}
The objective of this study is to analyze the hydrological regime of the Prahova River along its Carpathian and Subcarpathian stretches. The study reach has a length of $56 \mathrm{~km}$ and is situated between the Prahova River source and the downstream confluence with its main left tributary, the Doftana River. The description of the hydrological regime of the Prahova River is based on the statistical analysis of the climatic and hydrological data recorded at the meteorological stations and hydrometric stations in the area of interest. In order to understand the hydrological regime of the Prahova River, we focused on the following aspects: (1) sources of supply, (2) climatic factors (temperature regime, precipitation regime), (3) the mean flow, (4) the maximum flow (floods), (5) the sediment discharge and (6) the thermal and freezing regime of the Prahova River. The importance of this study lies in the need to know the hydrological regime that plays a leading role in the study of the morphodynamics of the Prahova River channel.
\end{abstract}

Key words: hydrological regime, statistical analysis, climatic factors, mean flow, floods, sediment discharge, hydrological nivo-pluvial regime.

\section{INTRODUCTION}

The hydrological regime sums up the set of hydrological characteristics of a watercourse and the way they vary (Musy, 2005). The definitions given by most authors indicate that the hydrological regime represents the daily, annual seasonal and multi-annual variations of liquid and solid flow rates, temperatures, chemistry, bedland processes (Lăzărescu and Panait., 1957; Musy, 2005; Zăvoianu, 2006; Ioana-Toroimac, 2009).

The variations of these parameters take place according to the factors that determine and condition the runoff formation: climatic factors (temperature and precipitation regime), geological characteristics, morphological characteristics, vegetation, soils and land use in the drainage basin. In addition to the natural factors mentioned above, an increasingly important role in the modification, sometimes even radical, of the hydrological regime of the watercourses is the anthropic factor (Zăvoianu, 2006, Jora et al., 2010).

The hydrological regime plays a pivotal role in the study of the river bed morphodynamics. Liquid and solid leakages are the factors that dramatically influence the time and space dynamics of the Prahova River bed. The liquid flow controls the size of the river bed while the sediment discharge is responsible for its stability or instability (Canciu, 2008). Also, besides the characteristics of river channel and rock in which the river bed may incise, the liquid and solid flows are the variables that have a determining role in the shape of the longitudinal profile.

\section{STUDY AREA}

The Prahova River headwaters is in the Clabucetele Predealului Mountains, in the Predeal step area, at an altitude of $1100 \mathrm{~m}$; it is a second order tributary 
of the Danube River and the first order tributary of the Ialomita River, the hydrographic basin having the shape of an amphitheater with an area of $3740 \mathrm{~km}^{2}$. The Prahova River basin has a large asymmetry with the left side occupying $88 \%$ of the total area of the basin (Pişota and Zaharia, 1994).

The Prahova River drains the territory of the counties of Brasov, Prahova and Ilfov along $193 \mathrm{~km}$ length, after which it flows into the Ialomita River at Dridu locality, downstream Adâncata settlement. As paved relief units, after springs from Predeal step, the Prahova River crosses the Carpathian chain, representing the geographical limit between the Southern Carpathians and the Eastern Carpathians. Then it continues its course through the Curvature Subcarpathians with a general NNVSSE direction of flow, and enters the Romanian Plain. The study area covers the mountain and Subcarpathian areas over a distance of $56 \mathrm{~km}$ along the river (Fig. 1).

From a geological point of view, the mountain sector of the Prahova River falls into the flish area. The Subcarpathian stretch extends to the north, in the Carpathian flish area, and to the south, in the structural area defined as the molasses area, which corresponds to the foredeep (Armaş et al., 2003).

Regarding the relief, the Carpathian stretch of the Prahova River is characterized by a transversal corridor with reaches in which the valley is narrow (the sector between Predeal and Azuga or between Sinaia and Posada localities), but it also spreads in certain areas (e.g. the depression basin where the Bușteni, Poiana Tapului, and Predeal resorts are located). The Subcarpathian reach is characterized by a large valley with a meadow and a system of 4-5 terraces.

From a pedological point of view, the districambosols, eutricambosols, luvosols, prepodzols, podzols and rocks predominate in the mountain sector. In the Subcarpathian area, eutricambosols, luvosols, preluvosols, erodosols, lithosols, faeosomes are encountered.

As far as the anthropic impact is concerned, it is well known that the mountain and Subcarpathic sectors of the Prahova River are to a large extent influenced by man-made activities, and are characterized by a high morphodynamic vulnerability (bank erosion and collapse, incision) (Armaș et. al., 2013, Gogoașe Nistoran et. al., 2018).

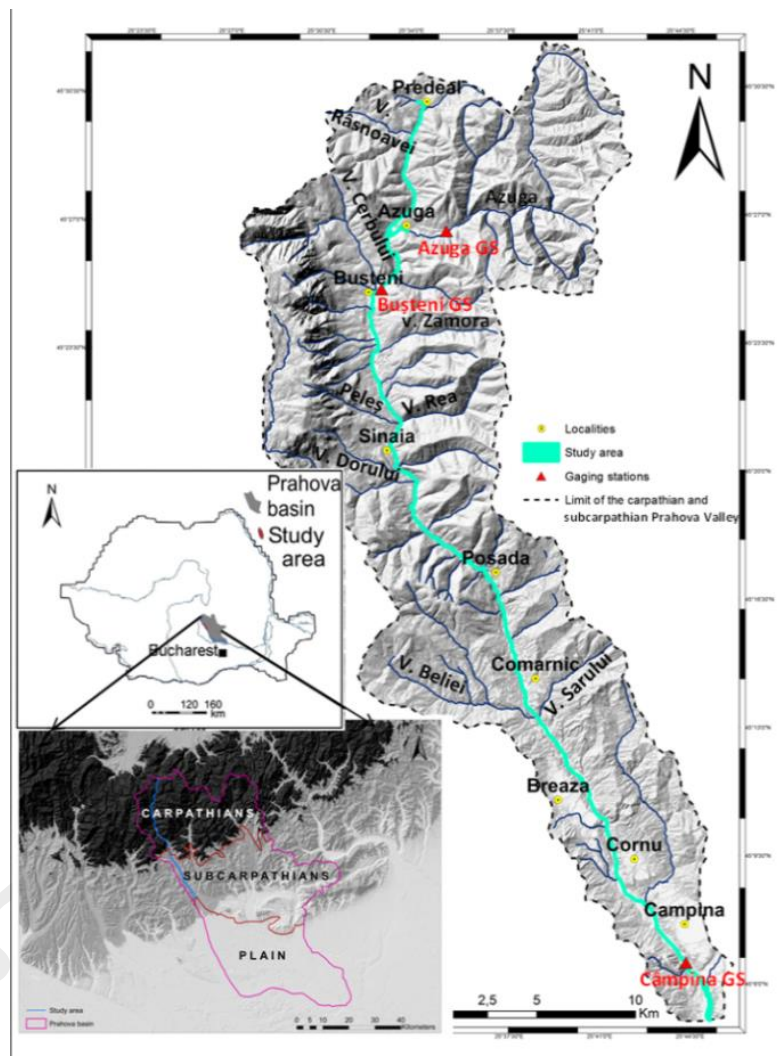

Fig. 1 Location of study area

\section{DATA AND METHODS}

The research was based on the use of climatic and hydrological data. The analyzed climatic data consist of chronological series of: air temperature, water temperature, daily rainfall, thickness of snow layer, thickness of ice layer. The data covers the period 1961-2012 and were recorded at the Predeal, Omu mountain peak, Sinaia and Câmpina meteorological stations. Climate data was provided by the National Meteorological Agency. Among the hydrological data used, we include: daily mean liquid flows, sediment flow rates, rating curves, daily mean water elevations, catastrophic (historic) floods, other hydrometric data measured at the gaging stations cross-section (velocity, top width, depth, wetted perimeter, hydraulic radius, water surface slope). All these data come from the Azuga, Poiana Țapului / Buşteni and Câmpina gaging stations (GS), covering the period 1960-2012, and were provided by the Water Directorate Buzău-Ialomiţa, 
Prahova Water Management System (S.G.A. Prahova, in Romanian).

In order to meet the objectives of this study, the above data were analyzed by statistical methods.

\section{THE TRIBUTARIES OF THE PRAHOVA RIVER}

Along the 56-kilometer-long study stretch, Prahova collects the flows of several tributaries. In the mountainous reach, the left bank tributaries, which drain the Clabucetele Predealului and Baiului Mountains are: Valea Puriştoicei or Poliștoaca, Azuga River, Valea Fetei, Valea Zamora, Valea Şipa, Valea Rea, Valea Câinelui. In the SinaiaPosada Gorge, the Prahova River receives along the left bank many torrents, of which the most important are: Valea Bogdan, Valea Razoarelor, Valea Floreiului and Valea Batrâioarei.

In the Carpathian reach, the right bank tributaries draining the Bucegi massif are: Valea Rîşnoavei, Valea Cerbului, Valea Albă, Valea Jepilor, Valea Urlătoarelor, Valea Peleșului, Valea Zgarburei, Valea Izvorului / Dorului. In the SinaiaPosada Gorge, the Prahova River receives on the right side numerous torrents, of which the most important are: Valea Largă, Valea Dracului, Valea Dogariei, Valea Măgarului.

In the Subcarpathian reach, Prahova receives only two more tributaries on the left side: Valea Sarului and Câmpinița. Because of the lithological conditions and complex structures, these valleys are characterized by intense torrential processes and landslides bringing a significant solid flow. In the Subcarpathian area, Prahova River receives on the right one single tributary, Valea Beliei.

\section{SUPPLY SOURCES}

Following the origin of the supply sources, the Prahova River has superficial or surface supply and underground feeding. Surface feeding is represented by precipitations that fall in liquid or snow form, and groundwater is represented by water table. Nedelcu (2010) states that, at the level of the Prahova drainage basin, rainwater sources account for $70-87 \%$ of the volume of the annual runoff, while the underground sources represent 13-27\%.

Referring only to the studied area, in the mountain sector of the Prahova River predominates the snow supply, where the thick snow layer stagnates on the valleys from November to MarchApril and may even continue to remain throughout the warm season in the shady areas (Mihai et al., 2016). Along the Subcarpathian reach the rain supply is predominant.

\section{CLIMATE FACTORS (TEMPERATURE AND PRECIPITATION REGIMES)}

In the process of runoff, climatic factors have a decisive influence on water reserves, both through the intake of rainwater and due to the losses caused by evapotranspiration.

The temperature regime - was registered at four meteorological (weather) stations: the lowest average temperatures recorded in January at Predeal are $-4.9^{\circ} \mathrm{C}$, at Sinaia are $-5.4^{\circ} \mathrm{C}$, at Câmpina $-1.8^{\circ} \mathrm{C}$, and only at the Omu mountain peak, due to the high altitude, the lowest average temperature is recorded in February at $-10.6^{\circ} \mathrm{C}$. In the hot season, the air temperature has positive values and the highest thermal average values are registered in July at Predeal $14.4^{\circ} \mathrm{C}$, in Sinaia $12.5^{\circ} \mathrm{C}$, at Câmpina $19.3^{\circ} \mathrm{C}$ and at the Omu mountain peak station, the highest thermal average occurs in August, being 5.5 ${ }^{\circ} \mathrm{C}$. In spring and autumn, the thermal average values remain predominantly negative in the high mountain areas while in the intramontane corridors with depressions and basins, the thermal average values lyes between $10-12^{\circ} \mathrm{C}$. In conclusion, in the studied area, the thermal regime is characterized by a peak in July (Predeal, Sinaia, Câmpina stations) and August (Omu mountain peak station), and by a minimum in January (Predeal, Sinaia, Câmpina stations ) and February (Omu mountain peak station).

The Rainfall regime. Rainfall was measured by precipitation gage at the Azuga (971 m altitude) and Bușteni (875 $\mathrm{m}$ altitude) gaging stations, in the Carpathians and at the Câmpina (378 m altitude) gaging station, located in the Subcarpathians. 
Monthly average precipitation recorded for the year 2009 (considered a hydrologically normal year), as shown in the graph in Fig. 2, show a maximum in the warm season, namely in June, July and August. The highest values were registered in July at Azuga $16 \mathrm{~mm}$, in Buşteni - $11 \mathrm{~mm}$ and in Câmpina - $7 \mathrm{~mm}$. The minimum values occur during the cold season (December, January and February) due to the predominance of the anti-cyclonic regime (Azuga $5 \mathrm{~mm}$, Bușteni $4 \mathrm{~mm}$ and Campina $3 \mathrm{~mm}$ ). Analyzing these data, we can see that rainfall values gradually decrease from the Carpathian area (Azuga and Bușteni) to the Subcarpathian area (Câmpina).

The pluviometric regime is characterized by two maxima:

- The first maximum rainfall occurs during the warm season (June and July): at Azuga $83 \mathrm{~mm}$ (July 2009), at Bușteni $61 \mathrm{~mm}$ (July 2009) and at Campina $42 \mathrm{~mm}$ (July 2009).

- The second pluviometric maximum is low and is recorded in October and November: Azuga $26 \mathrm{~mm}$ (October 2009), Bușteni $43 \mathrm{~mm}$ (October 2009) and Câmpina 33 mm (July 2009).

The pluviometric regime also has two minimums: a minimum is produced in the winter (January / February) and the second minimum is recorded in autumn.

\section{MEAN FLOW AND VARIATIONS}

Average flow is the most important indicator of water resources in rivers and is expressed by several parameters:

7.1. Mean multiannual flow $\left(Q_{0}, \mathrm{~m}^{3} / \mathrm{s}\right)$ is a parameter resulting from the arithmetic mean of daily flows over a period of years. The mean multiannual flow rates are small in the Prahova mountain sector (GS Azuga: $1.84 \mathrm{~m}^{3} / \mathrm{s}$, Poiana Ţapului / Buşteni: $4.14 \mathrm{~m}^{3} / \mathrm{s}$ ) and as the river enters the Subcarpathians, the values increase due to the intake of liquid flow coming from tributaries (GS Câmpina - $8.04 \mathrm{~m}^{3} / \mathrm{s}$ ) (Fig. 3).

If the average daily flows are listed in decreasing ordered, from highest to lowest, and if each value is assigned a probability of exceedance $(\mathrm{p} \%)$ per year (1-100), Q(p), or its analogous - the duration curve, $\mathrm{Q}(\mathrm{t})$, in days of a year is obtained (Fig. 4).

From this curve it may be seen that the annual flow has a probability of exceedance, $\mathrm{p} \%=38 \%$, corresponding to a return / recurrence period, $\mathrm{T}=1 / \mathrm{p} \%$ of 2.6 years, i.e. the flow that is statistically repeated every 2.6 years. Otherwise, statistically, for 139 days in an average hydrological year, the flow rate in the river channel is higher than the annual flow rate, while for the remaining 226 days, the flow rate falls below this value (Gogoașe Nistoran, 2018).

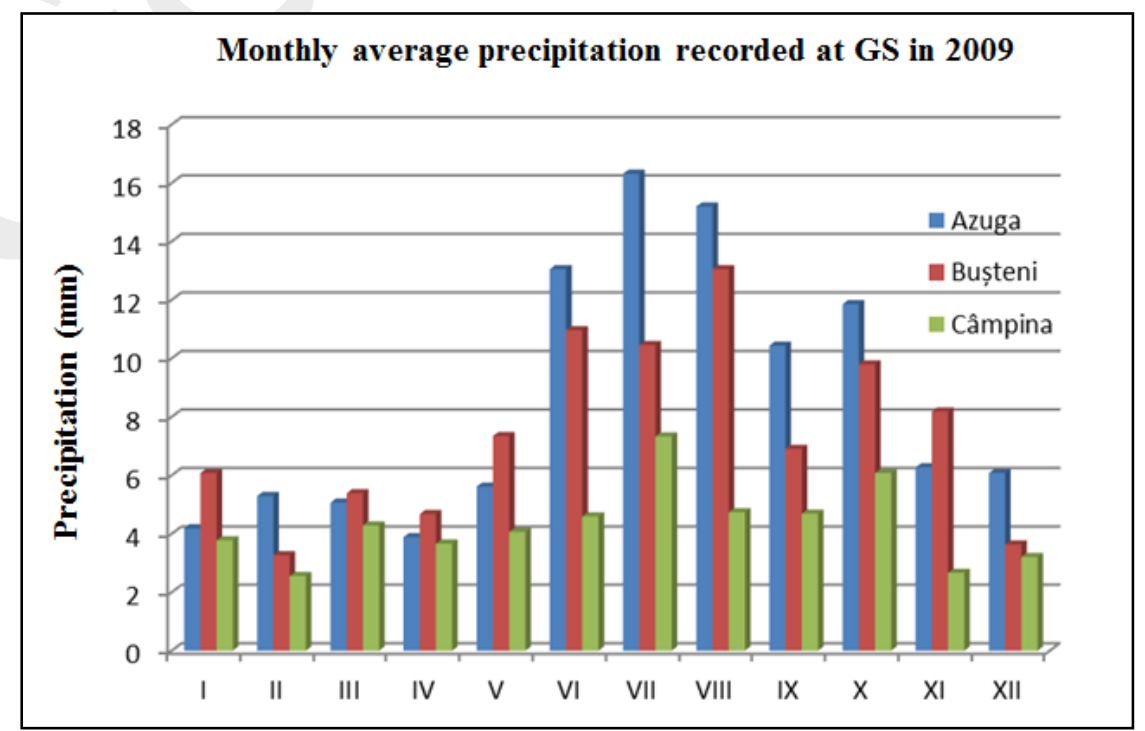

Fig. 2. Monthly average precipitation recorded at the three gaging stations in 2009 

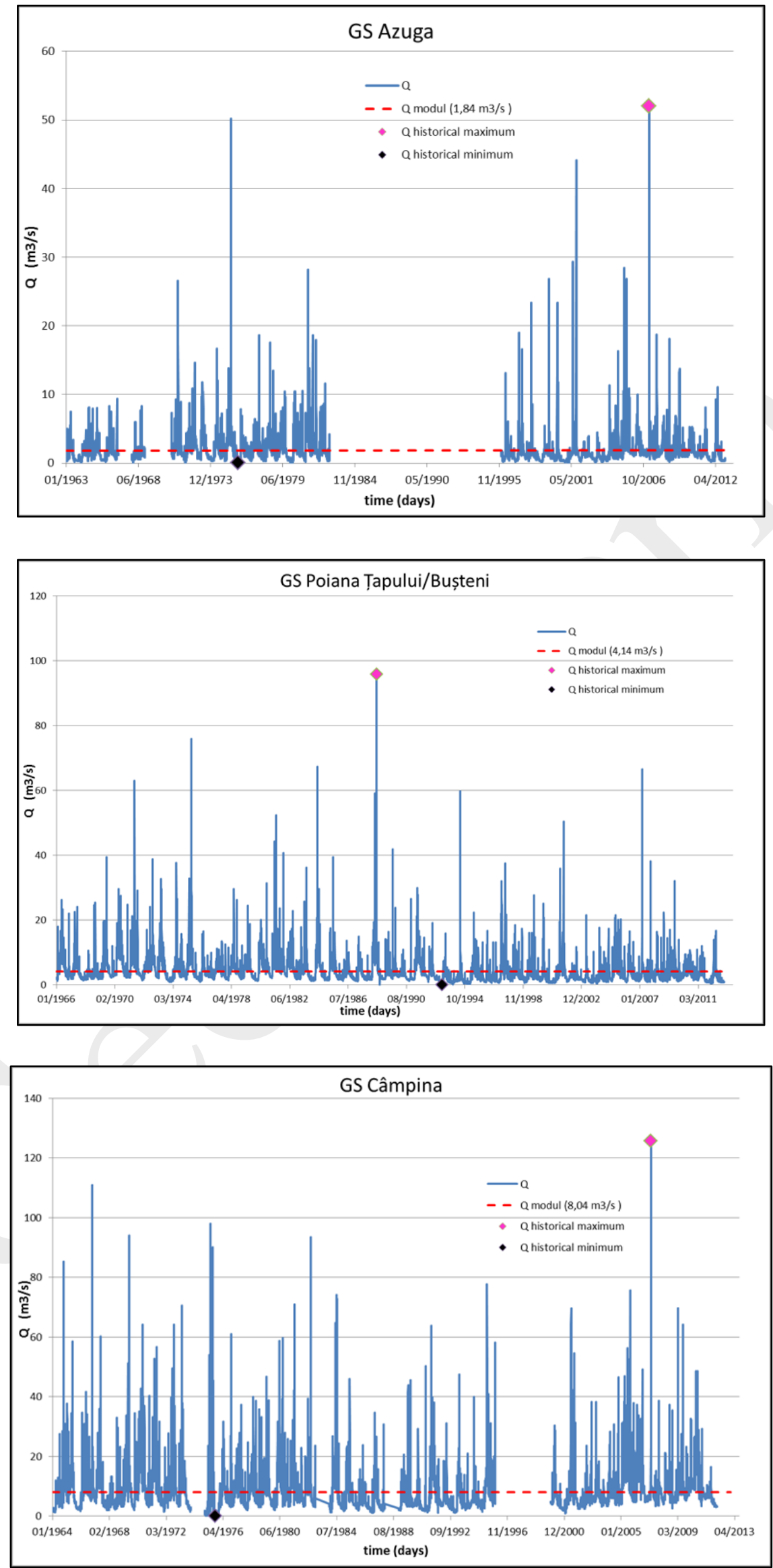

Fig. 3. Hydrograph of daily mean flows, $Q(t)$ recorded at the three GS along Prahova River (1963-2012) 


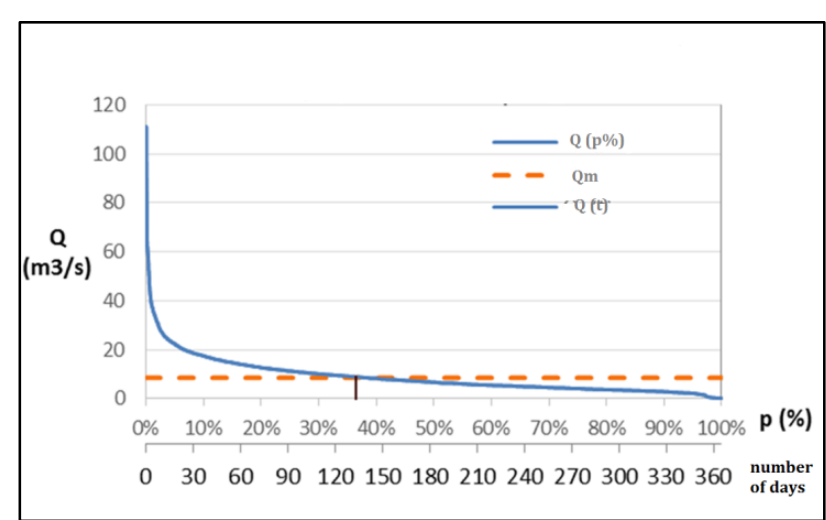

Fig. 4. Duration / probability curve of exceeding the mean daily flows at GS Câmpina

7.2. Mean specific flow $\left(q_{0}, l / s / \mathbf{k m}^{2}\right)$ is the parameter that shows the amount of water drained per second and unit area. In the studied area, the highest values are recorded in the mountain area, respectively at GS Azuga of $23.931 / \mathrm{s} / \mathrm{km}^{2}$ and GS Poiana Țapului / Buşteni of $23.78 \mathrm{1} / \mathrm{s} / \mathrm{km}^{2}$ and decrease in the Subcarpathians reaching at GS Câmpina $16.67 \mathrm{l} / \mathrm{s} / \mathrm{km}^{2}$.

7.3. The flow extremes result from the hydrographs of the recorded flows at the gaging stations located in the studied area (represented in the Fig. 3). Analyzing these hydrographs one can make the following observations: at GS Azuga, the maximum historical flow rate is $52 \mathrm{~m}^{3} / \mathrm{s}$, produced on 23 March 2007, and the minimum historical flow is $0,04 \mathrm{~m}^{3} / \mathrm{s}$ recorded at January 17, 1976; the maximum historical flow rate at Poiana Thapului / Buşteni GS is $95.9 \mathrm{~m}^{3} / \mathrm{s}$ registered on July 17,1988 and the minimum historical flow is $0.068 \mathrm{~m}^{3} / \mathrm{s}$ on March 2, 1993. At Câmpina GS the maximum flow rate of $125.64 \mathrm{~m}^{3} / \mathrm{s}$ was recorded on March 23, 2007, and the historical minimum flow was 0.044 $\mathrm{m}^{3} / \mathrm{s}$, on September 26, 1975.

7.4. The interannual variation of the mean, minimum and maximum average annual flows. From Figures 5, 6 and 7 it can be seen that at the Câmpina GS, the mean and maximum annual flows decreased slightly during 1964-2012, while the minimum annual flow has increased over the same period of time. At Poiana Țapului / Buşteni GS however, all these three annual flow values show a decreasing trend (Figures 8, 9 and 10).

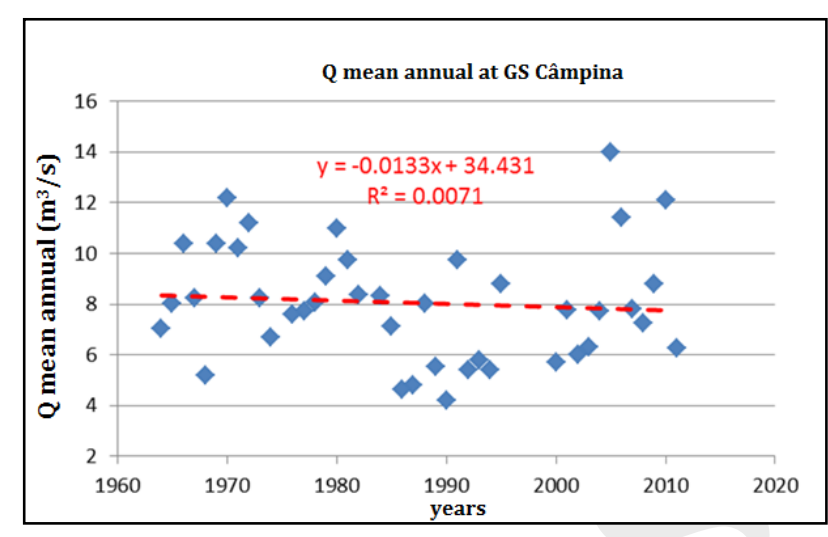

Fig. 5. Multiannual variation of mean annual flows at GS Câmpina

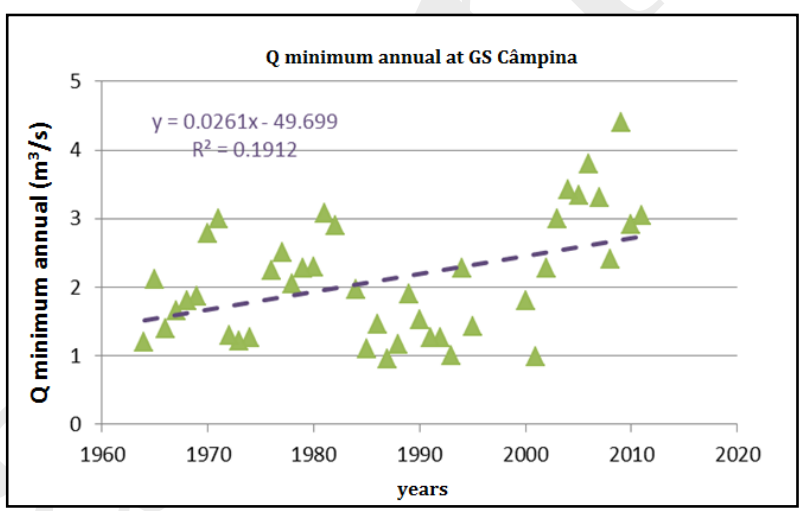

Fig. 6. Multiannual variation of minimum annual flows at GS Câmpina

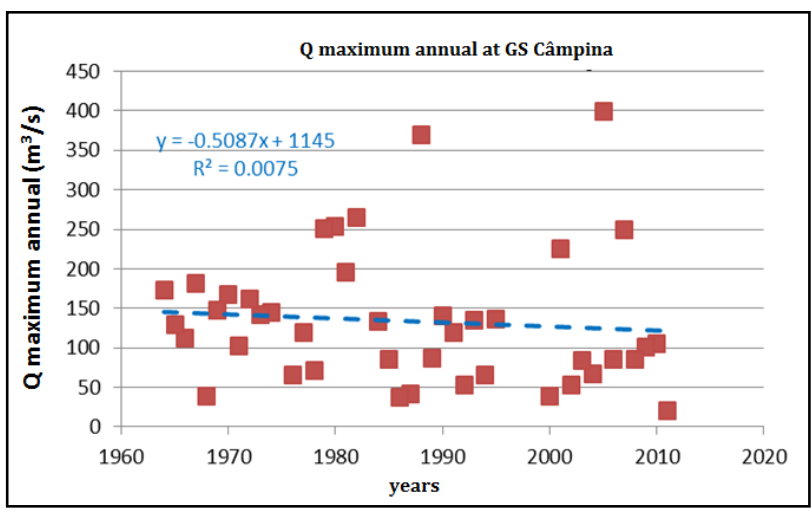

Fig. 7. Multiannual variation of maximum annual flows at GS Câmpina

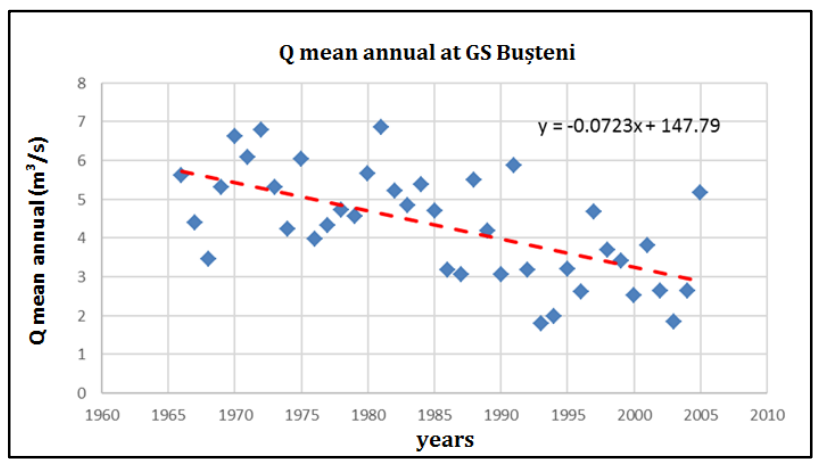

Fig. 8. Multiannual variation of mean annual flows at GS Bușteni 


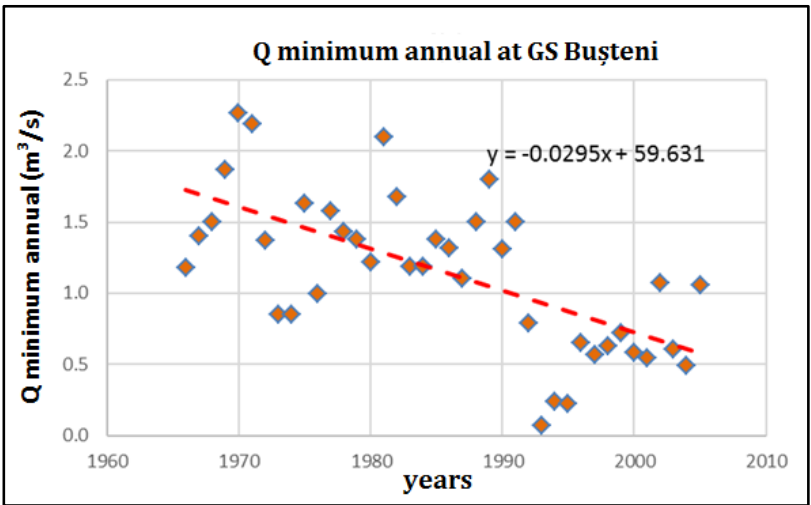

Fig. 9. Multiannual variation of minimum annual flows at GS Câmpina

7.5. Monthly and seasonal variations of flows recorded at gaging stations must be correlated with the temperature and precipitation regimes. Analyzing the graph in Fig. 11, one can see that the mean monthly flow reaches the first maximum during spring months (March-April) due to the increase in temperatures causing snow melting (Azuga of $3.65 \mathrm{~m}^{3} / \mathrm{s}$, Buşteni of $6.31 \mathrm{~m}^{3} / \mathrm{s}$, and Câmpina of $12.2 \mathrm{~m}^{3} / \mathrm{s}$ ), and a second maximum in the summer months (July-August), due to torrential rain from this season (Azuga of $3, .08 \mathrm{~m}^{3} / \mathrm{s}$, Buşteni of $6.12 \mathrm{~m}^{3} / \mathrm{s}$, Câmpina of $13.7 \mathrm{~m}^{3} / \mathrm{s}$ ).

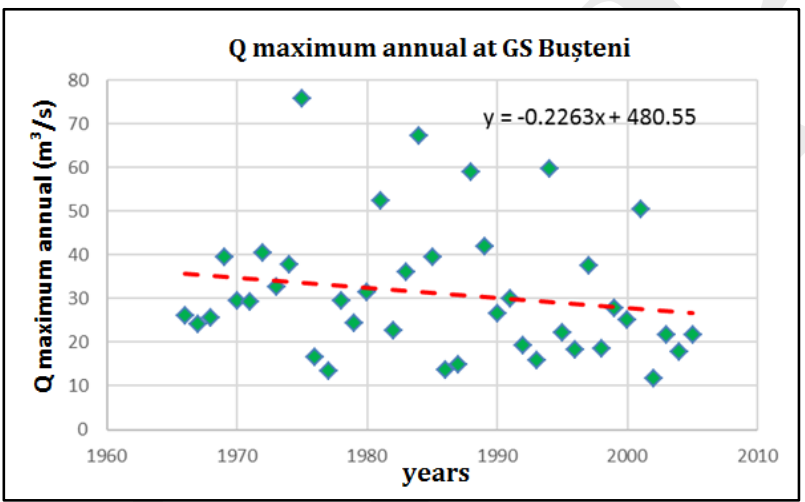

Fig. 10. Multiannual variation of maximum annual flows at GS Câmpina

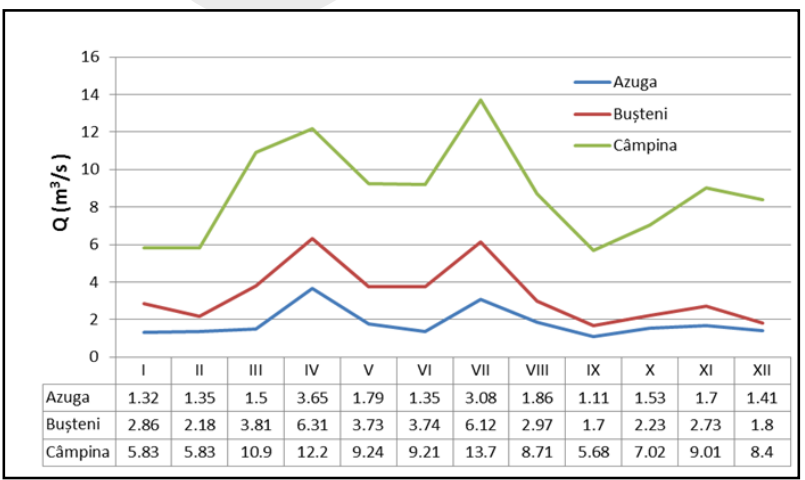

Fig. 11. Variations in monthly mean flows recorded at gaging stations in 2009
Minimum mean monthly flow rates are recorded during winter months (January-February) when the temperatures are very low and the precipitations fall in the form of snow (Azuga of $1.32 \mathrm{~m}^{3} / \mathrm{s}$, Buşteni of $2.18 \mathrm{~m}^{3} / \mathrm{s}$, Câmpina of $5.83 \mathrm{~m}^{3} / \mathrm{s}$ ). A second minimum is recorded during autumn in September (Azuga of $1.11 \mathrm{~m}^{3} / \mathrm{s}$, Buşteni of $1.7 \mathrm{~m}^{3} / \mathrm{s}$, Câmpina of $\left.5.68 \mathrm{~m}^{3} / \mathrm{s}\right)$.

7.6. The floods - are extreme hydrological phenomena that are characterized by sudden increases (bursts) in the level and flow of a watercourse due to torrential rains and/or snow melting. The floods may occur at any time of the year, but generally correspond to the spring months (March and April) caused by spring rains and snow melting, but occur also during the rainy years.

The most important floods that occurred on the Prahova River are:

The floods in 2007 - at all three gaging stations in the studied area; floods occurred in 2007 between March 18-31 and October 19-30. The March 2007 flood occurred due to the heavy rainfall experienced during this period. Rain gages installed at the stations recorded on March 23 maximum precipitations of $120 \mathrm{~mm}$ at Azuga, $105 \mathrm{~mm}$ at Buşteni and $30 \mathrm{~mm}$ at Câmpina. Under such rain conditions, on March 23, peak flows of $81.5 \mathrm{~m}^{3} / \mathrm{s}$ were registered along Prahova River at Azuga GS, of $102 \mathrm{~m}^{3} / \mathrm{s}$ at Buşteni GS and of $250 \mathrm{~m}^{3} / \mathrm{s}$ at Câmpina GS. The October 2007 floods were less intense and raingages recorded the highest rainfall this month on the 23rd, respectively $55 \mathrm{~mm}$ at Azuga, $51 \mathrm{~mm}$ at Buşteni and $26 \mathrm{~mm}$ in Câmpina. The peak flows recorded on the Prahova River on October 23 were: $25.4 \mathrm{~m}^{3} / \mathrm{s}$ GS Azuga, $55.2 \mathrm{~m}^{3} / \mathrm{s}$ GS Buşteni, $57.2 \mathrm{~m}^{3} / \mathrm{s}$ GS Câmpina. In Fig. 12 are the floods that occurred at GS Buşteni in 2007.

$>$ The floods in 2005; it is well known that in 2005 Romania was affected by high-intensity meteorological phenomena, which caused at least $50 \%$ of the normal rainfall to be exceeded. During this year, on the Prahova River, intense precipitation caused floods in May, July, August and September, when maximum flows reached historic values. In May, the rain gages recorded the maximum precipitation on the 7th, respectively: at the Predeal weather station there were of $51.2 \mathrm{~mm}$, at the Omu mountain peak station of $64.4 \mathrm{~mm}$, at 
Sinaia of $64.4 \mathrm{~mm}$ and at Câmpina of $16.2 \mathrm{~mm}$. These climatic conditions led to a peak flow of 147 $\mathrm{m}^{3} / \mathrm{s}$ at Câmpina GS. In July 2005, rainfall was higher than in May with a peak flow rate at Câmpina GS of $399 \mathrm{~m}^{3} / \mathrm{s}$, which is considered historic for this gaging station. High intensity floods also occurred in September, when on 19 and 20, the sum of the precipitations was $157.4 \mathrm{~mm}$ in Predeal, $43.6 \mathrm{~mm}$ at the Omu mountain peak, $194 \mathrm{~mm}$ at Sinaia and $226 \mathrm{~mm}$ at Câmpina.

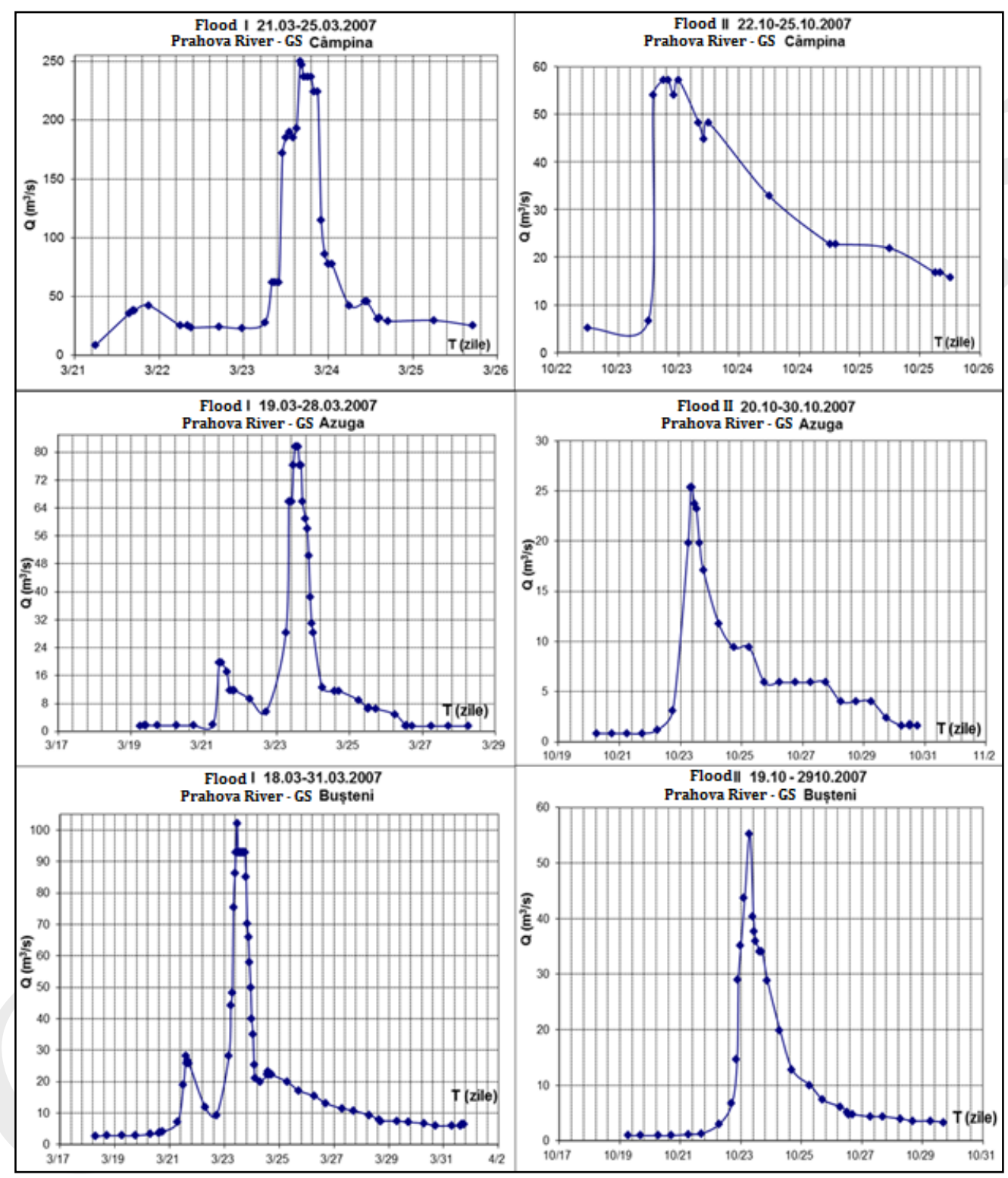

Fig. 12. The floods registered at gaging stations in 2007

Major floods occurred in 2001 when a peak flow rate of $92 \mathrm{~m}^{3} / \mathrm{s}$ was registered at Azuga GS, of $123 \mathrm{~m}^{3} / \mathrm{s}$ at Bușteni GS and of $110 \mathrm{~m}^{3} / \mathrm{s}$ at Câmpina GS. During the period 1960-2000, the most important floods occurred in 1975 when the raingages recorded on the $1^{\text {st }}$ and $2^{\text {nd }}$ of June 179 $\mathrm{mm}$ at Predeal weather station, $95 \mathrm{~mm}$ at the Omu mountain peak station, $157 \mathrm{~mm}$ at Sinaia and 144 $\mathrm{mm}$ at Câmpina stations. These abundant precipitations led to a peak flow rate in the river channel of $135 \mathrm{~m}^{3} / \mathrm{s}$ at Poiana T,apului GS and of $340 \mathrm{~m}^{3} / \mathrm{s}$ at Câmpina GS.

In Europe's mountainous areas, the duration of floods has decreased and their intensity has increased over the last decades, with a fast character (flash flood) (Alfieri et. al, 2016, Hall, 2014). In the study area this is mainly due to deforestation (vegetation delaying precipitation water runoff 
along slopes) and to the increase in paved (impervious) areas, which concentrates precipitation into the river channel much faster.

\section{THE SEDIMENT DISCHARGE}

From the point of view of the source, the total sediment flow transported by a stream represents the sum of the upstream river contribution and the riverbed contribution due to the effect of entraining the particles from the river bed into the stream water (Chanson, 2004, Graf, 1996). Consequently, the contribution and transport of sediment load into a river stream (which for the Carpathian reach can consist of sand, gravel, boulders, etc.) depends on the character of the sediments (size, density, nature, hardness, shape, granulometry, cohesion) and at the same time on climatic, hydrological, geological, morphological, and topographical features of all its upstream tributaries, as well as of the river itself along the study sector (Anderson et al., 1996).

From the point of view of the mode of transport, total load may be suspended or bedload solid discharge. The first consists of finer particles transported by the water stream and the second of coarser particles moved only at higher flow rates, specific to high water periods or floods.

The two types of sediment load are measured with different instruments and quantified with distinct formulas. Since dragging is very difficult to measure, especially on gravel beds, we will only refer to suspended load (flow).

Taking into account all the above-mentioned parameters, which underlie the formation and suspension of sediments, one can state that in the mountain reach of the Prahova River, characterized by low flows, compact rocks with high erosion resistance and high degree of afforestation, average suspended load has very low values. At the exit of the Prahova River from the Posada Gorge, the rocks are less cemented or even unconsolidated, being very friable and the soils have a loamy texture. Therefore, downstream this area there is a significant increase in the suspended flow. This is why systematic measurements of suspended load are only performed at the Campina GS, although in the studied area there are three gaging stations, as stated before (Fig. 1).
The interannual variations of the maximum and minimum annual suspended load have the same decreasing trend as the annual average values (Figures 13-15), since they are dependent on the corresponding values of the liquid flow rate (which also decrease). This may be due to: (i) the upstream Sinaia hydroelectric arrangements with small dams, (ii) river and tributaries hydrotechnical works to protect banks and riverbed of erosion, with concrete weirs, sills and stilling basins and (iii) aggregate extractions, especially in the existing gravel pits along the analyzed river stretch.

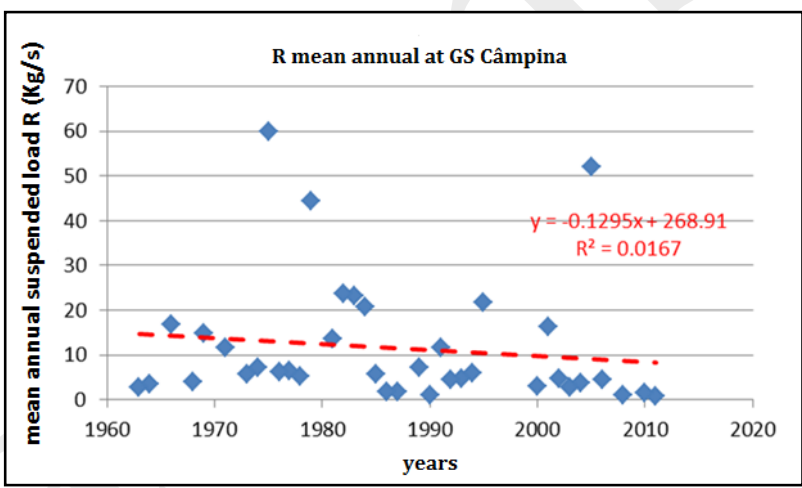

Fig. 13. Multiannual variation of the mean annual suspended load at Câmpina GS

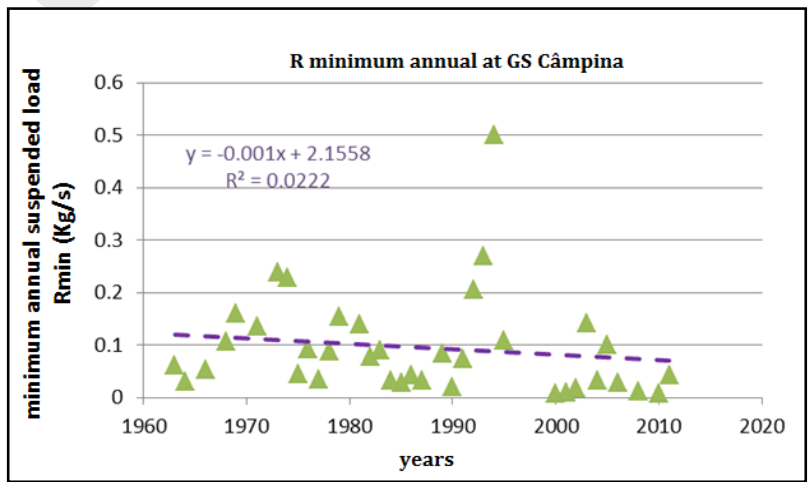

Fig. 14. Multiannual variation of the minimum annual suspended at Câmpina GS

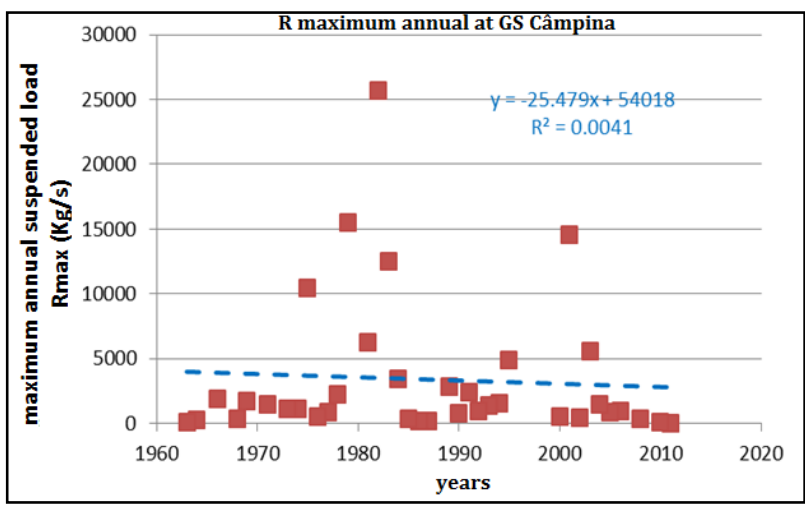

Fig. 15. Multiannual variation of the maximum annual suspended at Câmpina GS 


\section{THERMAL AND FREEZING REGIME}

The Prahova River water temperature varies from one reach to another, and this variation is closely related to the air temperature of the relief unit that the river crosses, the water dynamics, etc. Increasing altitude determines the decrease of the air temperature according to a vertical thermal gradient of $1{ }^{\circ} \mathrm{C} / 100 \mathrm{~m}$ which in turn influences the decrease of the water temperature. This assertion is supported by the records made at the three gaging stations in the studied area as follows: at the Câmpina GS (378 m altitude) the annual average is $9.8^{\circ} \mathrm{C}$, at the Buşteni GS (at an altitude of $875 \mathrm{~m}$ ) the annual thermal average is $5.9^{\circ} \mathrm{C}$ and at the Azuga GS (located at the altitude of $971 \mathrm{~m}$ ) annual thermal is $3.4^{\circ} \mathrm{C}$.

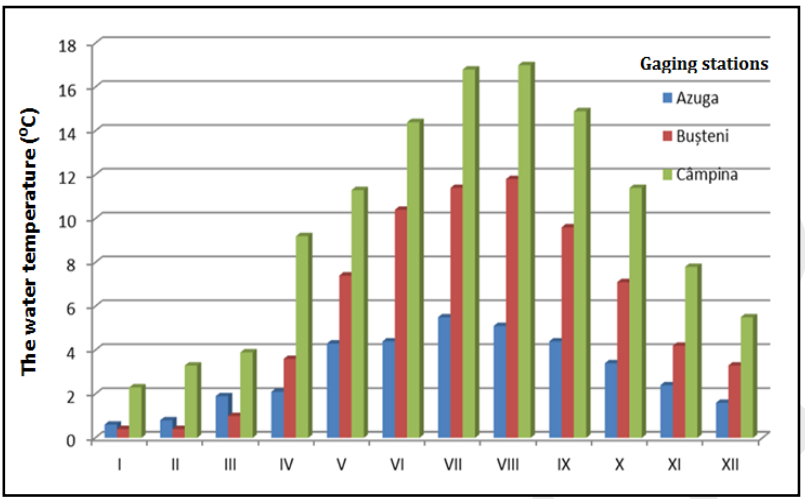

Fig. 16. Monthly average water temperatures recorded at the three gaging stations in 2009

Regarding the variation of the Prahova River water temperature regime during one year, we can see an increase in the average monthly temperature beginning with the snow melting in April and reaching a peak in July and August (Figure 16).

\section{CONCLUSIONS}

The present paper highlights new results that are in line with the previous literature.

Analysing the climatic and hydrological data, the hydrological regime of the Prahova River is characterized by high waters during the spring months (March-April), due to the increase of the temperatures causing snow melting and low waters during the winter months (January-February), when temperatures are very low and water is stored in the snow layer. A second maximum, which is much lower, occurs in some years in July-August due to torrential rains, and in other years at the end of autumn. The second minimum takes place in early autumn, in September. Thus, we can conclude that the Prahova River has a nivo-pluvial hydrological regime.

Interannual variations of mean, minimum and maximum annual flows over a period of about 50 years show a decreasing trend at Poiana T,apului / Busteni GS and Campina GS, with the exception of minimum annual average flow at Campina, which shows an unusual rising trend. While for the first GS a sudden fall in average flow values starting with 1993 might be explaind by the upstream location changing from Poiana Tapului to Bușteni, the overall interannual decreasing trend of annual flow values for both GSs may only be explained at this time scale, as either being due to climate change or to consumer-related anthropogenic impact in the Prahova River Valley area, which has the highest population density in the country.

\section{REFERENCES}

Alfieri, L, Burek, P., Feye, L. \& Forzieri, G. Global warming increases the frequency of river floods in Europe, Hydrol. Earth Syst. Science, 19, 2247-2260 (2015)

Anderson, J. L. 1996. A method for producing and evaluating probabilistic forecasts from ensemble model integrations. J. Climate, 9, 1518-1530.

Armaş, I., Damian, R., Șandric, I., Osaci-Costache, G. 2003. The vulnerability of slopes to landslides in the Subcarpathian sector of the Prahova Valley, Romania's Tomorrow Foundation Publishing House, Bucharest.

Armaș, I., Gogoașe Nistoran D.E., Osaci-Costache G., Brașoveanu L. 2013, Morpho-dynamic evolution patterns of Subcarpathian Prahova River (Romania), Catena, Vol. 100, pag. 83-99

Canciu, C., 2008. Valley of the Danube between Brăila and Pătlăgeanca - geomorphology study, $\mathrm{PhD}$ thesis, University of Bucharest.

Chanson, H. 2004. The Hydraulics of Open Channel Flows: An Introduction. Butterworth-Heinemann, Oxford, UK, $2^{\text {nd }}$ edition .

Gogoașe Nistoran, D. 2018 Modeling Hydrodynamic Changes Induced by Run-of-River Hydropower Plants along the Prahova River in Romania. Journal of Energy Engineering, (ASCE) 144 (2) 
Graf, W. L., 1996. Transport and deposition of plutonium-contaminated sediments by fluvial processes, Los Alamos Canyon, New Mexico, Geol. Soc. Am. Bull., 108, 1342-1355.

Hall, J. et. al., Understandint flood regime changes in Europe: a state-of-the-art assessment. Hydrol. Earth Syst. Sci. 18, 2735-2772 (2014)

Ioana-Toroimac, G., 2009. The hydrogeomorpho-logical dynamics of the Prahova River (Romania): current functioning, recent evolution and geographical consequences. $\mathrm{PhD}$ thesis in geography, University Lille 1, University of Bucharest, $341 \mathrm{pp}$.

Jora, I., Romanescu, G., 2010. Influence of anthropogenic activities on the hydrological regime of the Vaslui river. Water resources in Romania. Works of the First National Symposium, June 11-13, 2010, Târgovişte, Transversal Publishing House, Târgovişte, p. 201-208.
Lăzărescu D., Panait I. 1957. Types of river regime in R.P.R. Meteorology and Hydrology, 4: 22-37.

Lăzărescu D., Panait I. 1957 Hydrological Balance of Romania. Meteorology and Hydrology, 2 (4): 52-61.

Mihai, B., Buterez, C., Nedelcu, A., Cruceru I., Olariu, B., Rujoiu-Mare, M., Săvulescu, I., Tudose, I. 2016. Prahova county - space, society, economy, environment.. Romanian Academy Publishing House, Bucharest.

Musy, A., 2005.General Hydrology Course. http: //echo.epfl.ch/e-drologie/

Nedelcu, A., 2010. Prahova Valley and its fluvial system. University Publishing House, Bucharest.

Pisota, I., Zaharia, L. 1994. Prahova Basin Considerations on the Hydrological Regime, in "Annals of the University of Bucharest".

Zăvoianu, I., 2006. Hydrology. Romania's Tomorrow Foundation Publishing House, Bucharest. 